\title{
Development of Learning Models Courses in Introduction to Accounting And Utilizing Framework- Based Document Content Indonesian National Qualification as an Intervening Variable
}

\author{
Pandapotan Ritonga $^{1}$, Hafsah ${ }^{2}$, Tuti Angreani ${ }^{3}$ \\ \{rtg.dapot@gmail.com ${ }^{1}$ \} \\ 1,2,3 University of Muhammadiyah Sumatera Utara, Kapt.MukhtarBasri street, No. 3 Medan 20238 Telp: \\ 061 6619056, 6622400 Ext. 106 \& 108, Fax. $0616625474-66310003$ rtg.dapot@gmail.com
}

\begin{abstract}
The learning process contributes to the competence of the Indonesian National Qualifications Framework with a standardized coefficient of -0.878 and significant at 0.021. Lecturers and students contribute the Indonesian National Qualifications Framework competence with a standardized coefficient of 1.836 , and a significant value of 0.000 students and lecturers contribute with a standardized coefficient of 0.330 , and a significant value of 0.126 . Indonesian National Qualifications Framework competence gives contribution to the quality of learning with a standardized coefficient of 0.488 and a significant value at 0.040 . This goal is based on current conditions. Facts after the implementation of introductory accounting subject learning based on document content shows the results of changes in the teaching and learning process, where a lecturer who uses the results of discussion indicator output and lectures contributes to the learning process, amounting to 1,000 and 0.816 and significant value 0,000 . Furthermore indicators of difficult material assumption, learning motivation and learning techniques contributed to lecturers and students with coefficients of 1,000,1,142 and 0,992 and significant values of 0,000 . In addition the indicators of intervening knowledge mastery, managerial skills and the ability of the field contributed to the competence interesting variable of the Indonesian National Qualification Framework of $0.870,1,000$ and 0.935 and a significant value of 0,000 . Finally indicators of document content and readiness of lecturers contributed to the quality of learning by 1,000 and 0.939 with significant values of 0,000 .
\end{abstract}

Keyword: Learning model, Introduction to Accounting, Utilization of Document Content and Basis of Indonesian National Qualifications Framework.

\section{Introduction}

To reduce understanding and presentation in document content such as using invoices, receipts, receipts, etc., designing a Indonesian National Qualification Framework based learning model and utilizing document content in introductory accounting courses are still very much needed by students. This is intended to improve the quality of financial statements presented in accordance with the Financial Accounting Standards Statement through:

a. Providing guidance on the structure of financial statements including minimum requirements for each major component of the report, accounting policies and notes to financial statements;

b. Determination of practical requirements for problems relating to Materiality, business continuity, selection of accounting policies in the case of no regulation by PSAK, consistency and presentation of comparative information. 


\section{Literature Review}

System development projects generally include three general phases: system analysis, system planning and system implementation. System approach is a general procedure for system project administration. The aim is to help develop effective systems. The user-oriented system design philosophy will support behavior development and the system development approach will consider the organizational context. (George, 2000: 23-24).

\subsection{Ethics-business concepts and fundamental accounting}

The accounting profession has made several standards that are generally applicable and universally practiced a set of common standards called the generally accepted accounting principles - these standards govern how economic events are reported (Donald E. Kieso: 2012, $11)$.

\subsection{Learning that foster competence}

The learning process in accounting education is must be directed to the use of knowledge and abilities for the provision of life. Moreover, the learning process must pay attention to the balance of subordinate factors (interests, motivations, talents) and environmental factors will be able to bring achievement of learning objectives as expected by the students themselves. Therefore the lecturer plays the role as facilitator, innovator, and motivator for student learning, the individual learning process becomes very important by choosing learning methods that lead to discoveries and abilities and skills according to the wishes, interests, motivations, and talents of students.

\subsection{Documents}

GJ Renier $(2005$; 04) explains the meaning of the document in three senses, (1) in a broad sense, which includes all sources, both written sources and oral sources, (2) in a narrow sense that includes all written sources only, (3) in a specific sense, namely only those that include official letters and state letter such as agreements, invitations, concessions, grants and so on. Documents are letters or valuable objects, including records that can be used as evidence to support information to make it more convincing.

\subsection{Journals}

Journals are systematic and chronological records of financial transactions by mentioning accounts that will be debited or credited with a dissertation in their respective numbers and references.

\subsection{Ledgers}

Ledgers are those that contain all the names of the accounts in the financial statements. This book records changes that occur in each account name and at the end of the period the balance of the accounts will appear. Ledgers are a collection of accounts or estimates that are interrelated. 


\subsection{Balance Sheet}

Trial balance (balance sheet / balance list / residual list) is a tool used to collect the final balances contained in each ledger. If the amount of debit is equal to the amount of credit, it means there is a possibility that the recording is correct, but if it is not the same it means the recording is wrong.

\section{Research Methods}

\subsection{Place and time of research}

This research was carried out atMuhammadiyah University of North Sumatra and other Private Higher Education Institutions, as a comparison and improvement. The implementation of this research was planned from the 2017 budget year to 2018. For the second year the research was conducted for 8 months.

\subsection{Population and Samples}

This research was conducted at the Muhammadiyah University of North Sumatra and other Private Higher Education Institutions, as a comparison and improvement with the student population in 2 (two) universities namely MuhammadiyahUniversity of North Sumatra and Islamic University of North Sumatra with a sample of first semester students in 2 (two) colleges, namely Muhammadiyah University of North Sumatra and Islamic University of North Sumatra.

\subsection{Research model}

This research was seen from its objectives including development research because the research work steps began with exploration activities, model experimentation, evaluation and revision of the model.

\section{Results And Discussion}

\subsection{Research Results}

This structural equation model was indicated by the value of Chi-Squares $=79,033$ with the Degrees of freedom $=31$, and the probability of $p=0,000$. Likewise the value of other criteria such as GFI $=0.944$, AGFI $=0.901, \mathrm{TLI}=0.794$ whose value is above 0.70 and also the value of RMSEA $=0.77$. The probability value was 0 where the value was above 0.05 and other criteria that mostly fulfill well. These results indicated that the structural equation model met the criteria of model fit.

Model testing in the Structural Equation Model was carried out with two tests, namely the model suitability test and the causality test through the regression coefficient test. The variables proposed as indicators of the Learning Process were questions and answers and lectures. Results of confirmatory factor analysis (CFA) testing in Figure 1 


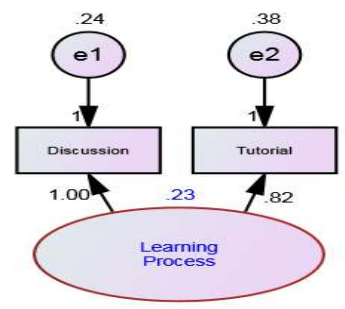

Fig.1. The learning process model.

From the two indicators of the learning process, namely: "Question and answer, and lecture" contributed to the learning process, the biggest contribution being question and answer amounting to, 82 percent and 100 percent lectures.

The variable proposed as an indicator of Students and Lecturers was the presumption of difficult material, learning motivation, and learning techniques. The results of the confirmatory factor analysis (CFA) test in Figure 2.

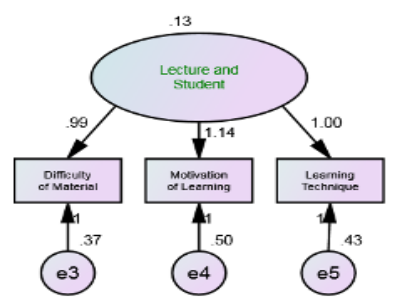

Fig.2. Student and Lecturer Models with.

The third was Student and Lecturer indicators, namely: "the presumption of difficult material, motivation to learn and learning techniques" contributed to students and lecturers, the biggest contribution of which was difficult material assumption of 99 percent. Learning motivation was at 114 percent.

The variables proposed as indicators of Quality of learning are Document Content, and Lecturer Readiness. The results of the confirmatory factor analysis (CFA) test without in figure 3.

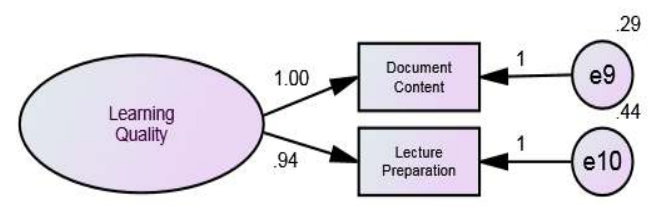

Fig.3. Learning Quality Model with.

From the two learning quality indicators, namely: "Document content, and lecturer readiness" contributed to the quality of learning, the largest was Lecturer Readiness of 94 percent.

The intervening variables proposed as indicators of Indonesian National Qualifications Framework competence were mastery of knowledge, managerial skills, and capabilities in the field of work. The results of the confirmatory factor analysis (CFA) test without in figure 4 . 


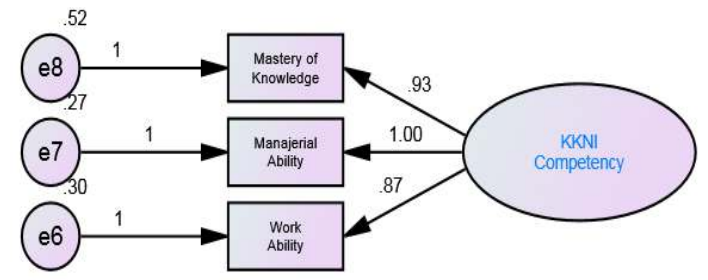

Fig.4. Indonesian National Qualifications Framework Competency Model.

The third was Indonesian National Qualifications Framework competency indicators, namely: "mastery of knowledge, managerial skills and capabilities in the work field" contributed to the competency of the Indonesian National Qualifications Framework, the largest contribution of which was 93 percent of knowledge mastery and 87 percent of fieldwork capabilities.

\subsection{Structural Equation Modeling}

From the results of the evaluation of the proposed model it turns out that all the criteria used show good results with the data. Guided by modification indices, the results in this case will be displayed Structural Equation Modeling learning process.

Table 1:Regression Weights: (Group number 1 - Default model.

\begin{tabular}{llllllll}
\hline & & & Estimate & S.E. & C.R. & P & Label \\
\hline $\mathrm{Z}$ & $<---$ & $\mathrm{X} 1$ & -.878 & .379 & -2.317 & .021 & \\
\hline $\mathrm{Z}$ & $<---$ & $\mathrm{X} 2$ & 1.836 & .506 & 3.626 & $* * *$ & \\
\hline $\mathrm{Y}$ & $<---$ & $\mathrm{X} 2$ & .330 & .216 & 1.530 & .126 & \\
\hline $\mathrm{Y}$ & $<---$ & $\mathrm{Z}$ & .488 & .238 & 2.049 & .040 & \\
\hline $\mathrm{X} 11$ & $<---$ & $\mathrm{X} 1$ & 1.000 & & & & \\
\hline $\mathrm{X} 12$ & $<---$ & $\mathrm{X} 1$ & .816 & .155 & 5.273 & $* * *$ & \\
\hline $\mathrm{X} 23$ & $<---$ & $\mathrm{X} 2$ & 1.000 & & & & \\
\hline $\mathrm{X} 22$ & $<---$ & $\mathrm{X} 2$ & 1.142 & .213 & 5.372 & $* * *$ & \\
\hline $\mathrm{X} 21$ & $<---$ & $\mathrm{X} 2$ & .992 & .184 & 5.384 & $* * *$ & \\
\hline $\mathrm{Z} 3$ & $<---$ & $\mathrm{Z}$ & .870 & .167 & 5.194 & $* * *$ & \\
\hline $\mathrm{Z} 2$ & $<---$ & $\mathrm{Z}$ & 1.000 & & & & \\
\hline $\mathrm{Z} 1$ & $<---$ & $\mathrm{Z}$ & .935 & .198 & 4.723 & $* * *$ & \\
\hline $\mathrm{Y} 1$ & $<---$ & $\mathrm{Y}$ & 1.000 & & & & \\
\hline $\mathrm{Y} 2$ & $<---$ & $\mathrm{Y}$ & .939 & .220 & 4.265 & $* * *$ &
\end{tabular}

Source: primary data processed 2018. 


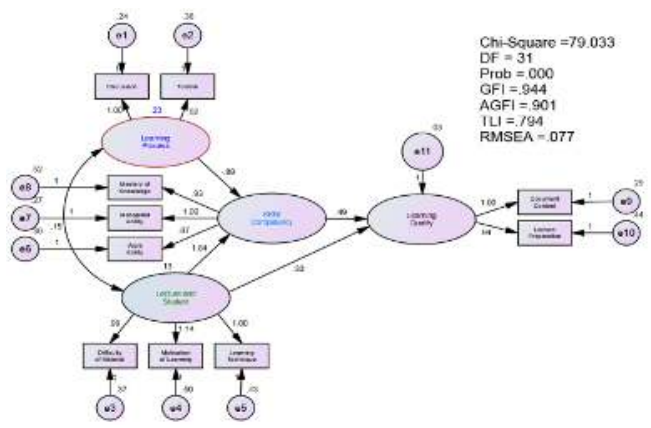

Fig.5. Structural Equation Modeling.

To test the relationship between the learning process, the Indonesian National Qualifications Framework competence and students and lecturers with the following learning qualities were presented path coefficients that showed a causal relationship between these variables. This relationship is shown in the structural equation modeling equation:

$Z=-0,88 X 1+1,84 X 2$, error var

$\mathrm{Y}=0,49 \mathrm{Z}+0,33 \mathrm{X} 2$, error var

\subsection{Discussion}

The following were the results of the analysis through the Analysis of Moment Structures program. There were two parts that we discussed, namely the estimated value of each parameter and the value of the accuracy of the model.

The learning process contributed to the competence of the Indonesian National Qualifications Framework with a standardized coefficient of -0.878 and significant at 0.021 . Lecturers and Students contribute the Indonesian National Qualifications Framework competence with a standardized coefficient value of, 1.836, and a significant value at, 0.000 , Students and Lecturers contribute with a standardized coefficient of 0.330 , and a significant value at 0.126 . Indonesian National Qualifications Framework competence gave contribution to the quality of learning with a standardized coefficient of 0.488 and a significant value at 0.040 .

The results of the discussion and lecture indicator output contributed to the learning process, amounting to 1,000 and 0.816 and a significant value of 0,000 . Furthermore the indicators of the assumption of difficult material, learning motivation and learning techniques were contributing to lecturers and students with coefficients of 1,000,1,142 and 0,992 and a significant value of 0,000 . In addition the indicators of intervening knowledge mastery, managerial skills and the ability of the field of work were contributing to the competence interesting variable of the Indonesian National Qualification Framework of 0.870, 1,000 and 0.935 and a significant value of 0,000 . Finally indicators of document content and readiness of lecturers contribute to the quality of learning by 1,000 and 0.939 with significant values of 0,000

\section{Conclusion}

a. This structural equation model was indicated by the value of Chi-Squares $=79,033$ with Degrees of freedom $=31$, and the probability of $p=0,000$. Likewise the value of other criteria such as GFI $=0.944, \mathrm{AGFI}=0.901, \mathrm{TLI}=0.794$ whose value was above 0.70 and 
also the value of RMSEA $=0.77$. The probability value was 0 where the value was above 0.05 and other criteria that mostly fulfill well. These results indicated that thestructural equation model met the criteria of model fit.

b. The learning process contributed to the competence of the Indonesian National Qualifications Framework with a standardized coefficient of -0.878 and significant at 0.02 . Lecturers and Students contributed the Indonesian National Qualifications Framework competence with a standardized coefficient value of, 1.836, and a significant value at, 0.000 , Students and Lecturers contributed with a standardized coefficient of 0.330 , and a significant value at 0.126. Indonesian National Qualifications Framework competence contributed the quality of learning with standardized coefficient of 0.488 and a significant value at 0.040 .

\section{Reference}

[1] Baridwan, Zaki., 2008. Intermediate Accounting.BPFE. Yogyakarta.Edisi Ke-8.

[2] Carl S., Warren dkk., 2015. PengantarAkuntansi. SalembaEmpat.Jakarta

[3] Degeng., I Nyoman S, Prof. Dr. MPd., 2000. Kumpulan BahanPembelajaran. LP3UM.Malang.

[4] Dryden., Gordon.,dan Dr. Jeannette Vos., 2001. Revolusi Cara Belajar. Kaifa.Bandung.

[5] Faud, Ramly.,\&Rustan., 2005. AkuntansiPerbankan. Grahallmu.Yogyakarta

[6] Gagne., Robert M. dan Leslie J. Briggs., 1974. Principies of Instructional Design.Holt, Rinehart and Winston.Inc. New York.

[7] George H.,Bodnar., William S., Hopwood., 2000. SistemInformasiAkuntasi. PenerbitSalembaEmpat.

Jakarta.EdisiKeenam.2003.SistemInformasiAkuntasi.PT.Indeks,

KelompokGramedia.EdisiDelapan.

[8] Gede, Muhammad Dr,. H,. M.BA, Ak.,\& Said KhaerulWasif, S.E., Ak., 2005. AkuntansiKeuanganMenengah 1. Jakarta: FakultasEkonomiUniversitas Indonesia.EdisiKedua.

[9] Hans Kartikahadid kk., 2012 .Akuntansi Keuangan berdasarkan SAK berbasis IFRS. SalembaEmpat. Jakarta Selatan.

[10] IkatanAkuntan Indonesia. 2009. Standar Akuntansi Keuangan. SalembaEmpat.Yogyakarta.

[11] Jerry J.,Weygandt Donald E.,Keiso Paul D. Kimmel., 2012. Accounting Principles.PenerbitSalembaEmpat. Jakarta.Edisi 7.

[12] Munawir, S., 2007.AnalisaLaporanKeuangan. Liberty. Yogyakarta.Edisi Ke-4.

[13] Mulyadi., 2001. SistemAkuntansi. PenerbitSalembaEmpat. Jakarta.EdisiKe 3.

[14] Niswinger- Fess- Warren.,Prinsip-prinsipAkuntansi. PenerbitErlangga. Jakarta.Jilid 1.Edisi K e-14.

[15] Poerwadarminta., 2005. KamusUmumBahasa Indonesia (Edisi KE- Jakarta: BalaiPustaka. Suherli, Michell\& Co.2006.AkuntansiuntukBisnisJasadanDagang.GrafiallmuYogyakarta.Cetakanpertama

[16] Scharg, Adele F.,dan Robert P.,Poland., 1987. A Sytem for Teaching Business Education.

[17] Sugiyono.,2013. MetodePenelitianKuantitatifKualitatifdan R\&D. CV Alfabeta. Bandung. 
[18] Syahrul., dan Muhammad AfdiNizar. ,2000. KamusAkuntansi. Jakarta: Citra Harta Prima.

[19] Warran, Carl S., James M. Reeve.,\& Philip E. Fess., 2005. PengantarAkuntansi.BukuSatu. SalembaEmpat. Jakarta. Edisi 21. 